\title{
LXIII. A sketch of the topography and geology of Lake Ontario
}

\section{J.J. Bigsby M.D. F.L. G.S.}

To cite this article: J.J. Bigsby M.D. F.L. G.S. (1829) LXIII. A sketch of the topography and geology of Lake Ontario, Philosophical Magazine Series 2, 5:30, 424-431, DOI: 10.1080/14786442908675038

To link to this article: http://dx.doi.org/10.1080/14786442908675038

册 Published online: 10 Jul 2009.

Submit your article to this journal $₫$

Џ Article views: 2

Q View related articles $₫$ 
the sphere of the heavens, for instance, if one hemisphere be projected on the same plane, the form of the configurations of the stars is entirely lost, and the map ceases to bear any resemblance to the appearance presented to the eye. This would not be the case if the sphere were projected upon six planes forming the sides of a cube, the eye being supposed at the centre. The distortion at the corners would be too trifling to interfere sensibly with the effect to be produced. The heavenly sphere would thus be contained in six maps, which would have the advantage of enabling any one to find any star or constellation with the greatest readiness. If the pole be taken for the centre of the upper surface of the cube, and the maps be divided by meridians and parallels of declination, the sides of the cube are symmetrical, the parallels of declination are portions of hyperbolas, and the meridians are straight lines; the upper and lower surfaces are also symmetrical, the parallels of declination are circles, and the meridians are straight lines.

LXIII. A Sketch of the Topography and Geology of Lake Ontario. By J. J. BrGsby, M.D. F.L. and G.S., For. Mem. Amer. Phil. Soc. \&c.

[Concluded from p. 347.]

7 TE next place at which I have met with conglomerate is 1 seven miles above this strait, close to a well-marked bluff promontory. Here the cement is in great quantity; and is clay, coloured by chlorite: the quartz nodules are often red, and are both rounded and angular. It is at the water's edge. Some hundred yards below the deposit of schorl on Mr. Mackenzie's farm before spoken of, elevated strata of milky quartzrock make their appearance on the beach, accompanied by the granular gneiss, containing schorl and chlorite. Resting in close contact on the quartz is a coarse conglomerate of the same materials, in a green cement; and above it is an horizontal brown limestone, full of quartz nodules at the bottom of the ledge, but which, gradually diminishing in number and size, disappear almost wholly in the upper layers. This very coarse conglomerate of milky quartz forms a ledge fifteen feet high, about three hundred yards south-west of the same deposit of schorl, close to a creek on Mr. Mackenzie's farm, and is again filled with fragments of the last-named mineral. It is in this case surrounded by debris and soil, and therefore is, as far as we can observe, unconnected with any rock. These puddingstones seem to be merely local deposits, thick and extensive as we have seen them to be; for on the shores of the 
outlet near and east of Kingston, in numerous places, limestone rests upon the gneiss without the intervention of a third rock; and on the slope of Point Henry under the west side of the Fort, the primitive rock is immediately overlaid by a breccia, whose remarkably angular fragments are of the greenstone and sienitic gneiss (or granite) of the place exclusively. I observed that the cement was a somewhat crystalline limestone, and that the large and small fragments were kept separate. Very little of this breccia is visible, neither can there be much; for it is surrounded by fixed masses of the gneiss and of limestone, horizontal or slightly inclined to the west. Shreds of this last rock are occasionally seen attached to the gneiss of the promontory close to Cedar Island and (as before mentioned) in parts of the outlet. Its adhesion is so strong that it is easy to obtain hand specimens composed of both rocks in firm union. The age of this sandstone is determined by that of the limestone incumbent on it to be that of the old red sandstone. The limestone in every circumstance but its horizontality (or near approach to that position) is similar to the carboniferous of England. Their most characteristic organic remains and minerals are the same; as also their relations, at least to the rocks beneath them.

In the same form as on the lake shore, this limestone (whose situation and characters we shall now trace) occurs in the valleys and small elevated plains interspersed in the adjacent primitive formation. It is horizontal, as far as the eye can judge, and never under the sandstone or conglomerate. From Brockville upwards, it skirts the outlet at some distance from its banks, which are always (except as noted above) of sandstone and gneiss; thus the eminence in the rear of that town is calcareous, while the cliffs in front and on its east are arenaceous.

The town of Kingston is based upon it, and it is to be traced westerly for seventy miles to the Portage of the Bay of Quintè at least, and southerly to the south shore of Lake Ontario; while in the two remaining directions it terminates on the older inclined rocks. At Kingston it forms extensive and high platforms behind the town, which first by a ledge, and then by broken shelves, gradually descend towards the shore to the level of the lake. Points Frederic and Henry are faced by it in low precipices; and the latter has many quarries of it in the hill east of the fort. The lake of the mountain in the Bay of Quintè is underlaid by this limestone, and discharges into the bay over a precipice (at a rude guess) 120 feet high. I had no opportunity of examining this locality; but was more fortunate at Hallowell, about thirty-six miles west of Kingston, N.S. Vol. 5. No. 30. June 1829.

where 
where at a wharf there is a steep limestone rock about ninety feet high, but not absolutely perpendicular.

On the peninsula of Prince Edward, I am informed there are some very high cliffs; I have not seen them. Quintè Portage, and the Presquisle Point, three miles W. of it, rest upon this limestone. The north main adjoining Quintè Bay is in gentle undulations, occasionally high enough to be called ridges. It is highly fertile, and supports an opulent yeomanry. The River Nappanee, thirty miles west of Kingston, besides presenting some remarkably pretty scenery, exhibits at its lowest Falls a fine vertical section of the limestone.

At Kingston there is discovered at least one hundred feet perpendicular of this rock; I believe that the form in which it is found here may be taken as a type of the whole, with some exceptions to be stated afterwards. Its layers are from six to eighteen inches thick, with rough floors and roofs; often coated with a thin black glaze which scales off: occasionally they are quite shaly. "The subdivisions in the strata, which from their singular shape have been called sutures, are seen in most of them at this place; but they are very irregular in size and number: sometimes there are many in a small layer, and none in a large one. They are not continuous for any distance, but disappear in the form of a fissure. They are commonly, but not always, horizontal. They often form a sort of irregular knot (as in wood) in the middle of a stratum." (Vide Niagara, Geology of.) - The highest strata, those of the upper platform, are blue, fine-granular, of conchoidal fracture, and are everywhere crowded with a great variety of organic remains, while none are found below. 'The latter are studded, in most places, with small masses of hyaline calcspar (as at Marmora), and are usually of finer texture than those above, even so much so as to be quite compact, sharp-edged, and of highly conchoidal fracture. The hardness is also somewhat increased; and the colour changes to a brown, which in the middle and lower portions is quite a'gray, with sometimes a greenish tinge. The strata near the beach are usually much weathered. The limestone of Point Henry adjacent, differs but little from that of Kingston, but is destitute of organic remains, although their respective highest layers are at nearly the same level; but those of Kingston have a much greater body of rock interposed between them and the gneiss than the strata of Point Henry, which are only a few feet distant at most. The inferior layers of this point are well developed in a quarry on the south of the fort. It is blue at the top, then greenish and more granular (as if weathered) for four or five feet; then clove-brown for 
more than a foot, when the green form returns for the same thickness as befure, and is followed by the common pale-brown limestone down to the beach.

The blue limestone of Catarroque (one to three miles W. of Kingston, and ten to thirty feet above the lake), with that of the higher parts of Point Henry and of the terraces among the primitive rocks ten miles N.E. of Kingston, contain large masses of red and white calcspar, with octohedral iron pyrites imbedded or in druses, and of fibrous celestine under similar circumstances. Sometimes the celestine is by itself in balls from an ounce to ten pounds in weight, in promiscuously aggregated bundles of closely compacted fibres of a beautiful skyblue colour, of a silky lustre and often pale. Geodes of trihedral pyramids of calcspar are not uncommon, with a delicate network composed of the fibres of celestine running along the apices of the crystals. The cliffs and ledges of brown limestone on the shores of the outlet on Mr. Law's farm contain shapeless masses of white foliated strontian. I have not met with this mineral in any other part of the north shore of this lake. It is plentiful in other forms, in this and more recent limestones, in different parts of the valley of the St. Lawrence. The varieties to which I have alluded, consist of the large crystalline brown kind full of shells, found at Stony Island near Sacket's Harbour, Carlston Island, and at Quintè Portage. It is usually in the upper layers. For ten miles west of the village of Bath ( miles W. of Kingston) there are several naked patches of brecciated limestone, the masses being pale blue and brown, while the cement is of the same colours, but much darker. In the woods between Marmora works and Lake Ontario this breccia is not at all uncommon in the state of displaced (but not rolled) fragments. Its situation in the carboniferous limestone of this vicinity $I$ do not know. The Hallowell limestone is of a dull leaden brown, and is in thin layers. It contains the conularia so characteristic of the abovementioned rock.

In regard to the succeeding rocks of Mr. Eaton's series, I have met with nothing indicative of the presence of his grauwacke and millstone grit, either in a fixed or loose state; further inquiries may find them : while nothing like his ferriferous slate and sandstone are visible, the saliferous rock undoubtedly prevails throughout the north shore, both in the immediate vicinity of the lake and as much as twenty miles in the rear. As far as I am aware, it is only detected by its springs. The first intimation of their existence is usually given by cattle. They occur in swamps, ponds, and runuing brooks in the woods, where no strita are in sight, and where those close at hand 312 
and on the same level contain producte, orthocerc, trilobites, \&c. They are tolerably copious; and although weak at the surface are more concentrated below, where they are no longer diluted by rains and infiltrations. The following are the situation of the springs of which $I$ have received intelligence; but I confess that I have not hitherto made sufficient inquiries.

In the centre of the township of Elizabeth's Town, on the east of the primitive band crossing the lake of the Thousand Islands, there is a spring (Gourlay, vol. i. p. 511); another, together with gypsum, in Ernest Town on the shores of the lake (Gourlay, vol. i. p. 483); another in Sophia's Burg on Prince Edward's Peninsula (Gourlay, vol. i. p. 146). Besides many smaller salt licks, in front of lot, No. 10, in concession B of the township of Murray, one and a half to two miles N.W. from Quintè Portage, there is a saline spring which discharges as much as a common pump. It has been penetrated for sixteen feet, and yields about a peck of salt for every seventy gallons of water; but it is supposed to be weakened at present by the stagnant brackish water which surrounds the spring in patches for a quarter of a mile square.

There are several salt springs in the township of Percy, county of Northumberland, at which much salt was made during the war between Great Britain and the United States. There are several also in the township of Whitby, in the East Riding of the county of York, issuing from clay and increasing in strength with the depth from which they are raised. Others are at Chinkecushè on the River Credit in the township of Toronto; in the seventh concession of Esquising; and many about Burlington Bay; and at St. Catharine's on the west shore of the lake; some of which are worked, and will be noticed hereafter. Nothing but capital, and a little practice, is wanting for them to be as productive as the saline springs of the State of New York.

The unbroken continuity to at least three miles beyond Quintè Portage of the carboniferous limestone of Kingston, incumbent on gneiss, renders it very difficult to account for the presence of salt in Ernest Town, Adolphus Town, and in Murray. I think that in this interval I have seen the rock in undisturbed horizontality at least every three miles, and characterized by its peculiar organic remains in the clearest manner. Among them are, conularia, Llandilo, and trilobites (Asaphus) turbinite, producte, orthocerce.

This difficulty is felt particularly in Murray, where the carboniferous limestone is quite near, and I believe floors the low marsh in which the springs appear.

To suppose that the strata at and for three miles west of Quintè 
Quintè Portage dip to the N.W., would relieve us from the dilemma by placing the salt rock above them; but the shreds of limestone visible in those places are horizontal : neither is it usual for the newer rocks to incline towards those more ancient supporting them, they usually incline from them.

In the basin of Lake Ontario, we have not so decidedly the aid of the organic remains in investigating the relative ages of the strata. There is no doubt of the situation of the carboniferous and calciferous limestones on the south shore; for instance, the former is beneath the salt rock, and the latter above it; yet they both contain orthoceratites, trilobites, productce, \&c. differing however in species.

Leaving these difficulties to be unravelled by future observers, I shall proceed to mention, that although I have carefully travelled over the distance, I have not seen fixed limestone from within three miles of Quintè Portage* to York (107 miles), excepting a few weathered strata at Hamilton's Creek (sixty-seven miles E. of York) and Port Hope (sixty miles E. of York). At these two places it floors the streams, and is both compact and crystalline in the same layer: it contains the fossils of carboniferous limestone, and so for the present must be arranged as such.

Near Still's Tavern, thirty miles east of York, and not far from the lake, I am told there is a small patch of black calcareous shale having chiefly trilobites imbedded in it. I did nut visit the spot. This shale may belong to the calciferous slate of Eaton, above the saliferous and ferriferous rocks, - a supposition greatly strengthened by the nature and contents of the limestone about the fort at York, at the mouth of the adjacent River Humber, and for six or eight miles up it, where there are extensive quarries. Dr. Lyons, surgeon to the forces, informs me that it is in horizontal layers of moderate size, and that it contains the genus Caryocrinites of the Crinoidea. It cannot be distinguished in hand specimens from some of the calcareous beds in the calciferous slate; and now and then, like them, contains silvery scales, very small, of mica or talc. It is brown with a slight tinge of green, granular and hard. In addition to great numbers of large orthocera, terebratula, productee, encrinital columns, \&c. it contains also many modioli, and plagiostoma, organic remains, which, with the encrinital stomachs just alluded to, have never been found in the carboniferous limestone of Canada, but frequently in the calciferous slate. The number of fragments of trilobites

* It is seen in broken ledges at the points, but chiefly under water and much changed. I had it not in my power to examine it. 
occurring in some of the layers is inconceivably great, but they are too small to allow of the determination of the genus.

Such are the rocks of the north shore of this lake. We have seen that their examination is greatly embarrassed, if not altogether prevented, in the western half of the interval between Kingston and York, by morasses and extensive deposits of alluvion. The same obstacles, I learned, exist from York to the head of the lake; so that, discouraged also by the state of my health at the time I was in that neighbourhood, I did not proceed on the north shore further west than the last-named town.

The south side of the upper end of the lake, constituting part of the district of Niagara, I have examined carefully. I found the rich and beautiful stripe of low land between the lake and what is called the "mountain," to be underlaid by saliferous sandstone, in extremely thin and soft stratu, red, green and blue, and very argillaceous. It is visible on the River Niagara at the Gorge of Queenston, and in the river bank at the town in great thickness. Many of the creeks between the Niagara and Burlington Bay have worn their way down to it; and the brackish waters called "deer-licks" are not uncommon. I visited one of these, three quarters of a mile W. by N. from the village of Stoney Creek. It is in a hollow, and is merely a quantity of muddy brackish water on a bottom of blue clay, evidently much frequented by animals, from the trampled state of the herbage and smaller trees around it. These strata come very fairly into view at Big Creek, eleven miles west of the village of Grimsby on the Forty-mile Creek. There are here two salt-works on a very small scale, belonging to Messrs. Kent and Macdougal. They are only a few hundred yards apart, and are both in a hollow, formed by the creek, but now, at least in autumn, deserted by it. The saline rock shows itself in a high scarp and some small crumbling ledges, and is quite in the usual form. Mr. Macdougal's works yield sixty-five bushels per week (1824), and could produce a hundred if necessary. The water is very weak, and scanty. The spring may be pumped dry in an hour. There is a well for the first twelve feet, and then a bore for seventy feet further. Mr. Kent's spring is in the same circumstances as the one just described. These few particulars I obtained from one of the workmen on the spot.

At the flourishing village of St. Catharine's, twelve miles from Queenston, there is another salt-work, close to the Twelvemile creek, whose bed is 100 to 120 feet below the average level of the country, and flanked by steeps of red clay, sand, and quartz pebbles. It is in the red saliferous rock. The 
Mr. Nixon on the Heights of the Hills of Wensleydale. 4.31

boring has been carried 250 feet below the surface, but with occasional changes in the strata. What these were I was unable to learn; Mr. Merritt, the proprietor, being absent at the time. While the water of the creek, only a few feet off, is quite sweet, that of the spring is very salt, and copious. It is sometimes very red. Fifty gallons make a bushel of salt, which is very white, and in small and thin irregular tables; 3640 bushels are made in a year, worth on the spot about $550 l$. sterling.

The Parallel Ridge, a mountain overlooking this flat, is composed of the same materials as the chasm of the River Niagara, which have already been declared to be, successively, from below, saliferous sandstone, ferriferous sandstone and slate, calciferous slate, and geodiferous limestone rock. I therefore refer the reader to my account of that river for any additional particulars respecting these strata that may occur in that ridge.

J. J. BIGSBY.

LXIV. On the Measurement (by Trigonometry) of the Heights of the principal Hills of Wensleydale, Yorkshire. By JoHN Nixon, Esq.

[Concluded from page 362.$]$

SOME time previous to the commencement of the survey, $D$ the great levels of the horizon-sector had been fitted up with scales divided into equal parts (of about two seconds each), numbered from the end of the scale the nearest to the eyepiece of the telescope progressively to the one next to the object-glass.

The zero of each index (carrying the levels) being placed exactly in a line with that of its graduated arch (fixed to the telescope), on which it moves, the following method was adopted in order to ascertain at what two divisions of its scale the bubble of each level would remain stationary on reversing the telescope within its Ys.

The sector, placed in the shade on a perfectly steady support (such as a rock or well-built wall), having acquired the temperature of the ambient air, the inclination of the telescope was varied until the bubble of either level; for instance, that of the right index, moved to about the middle of its scale. After a lapse of a few minutes, the divisions of the scale coincident with the two extremities of the bubble were read off and registered. In the second place, the telescope was inverted within its $\mathrm{Ys}$, and the corresponding position of the bubble of the left-index level (now uppermost) read off. Lastly, the telescope 